\title{
A memorabilia esquiva do Teatro do Vestido
}

\section{Rui Pina Coelho}

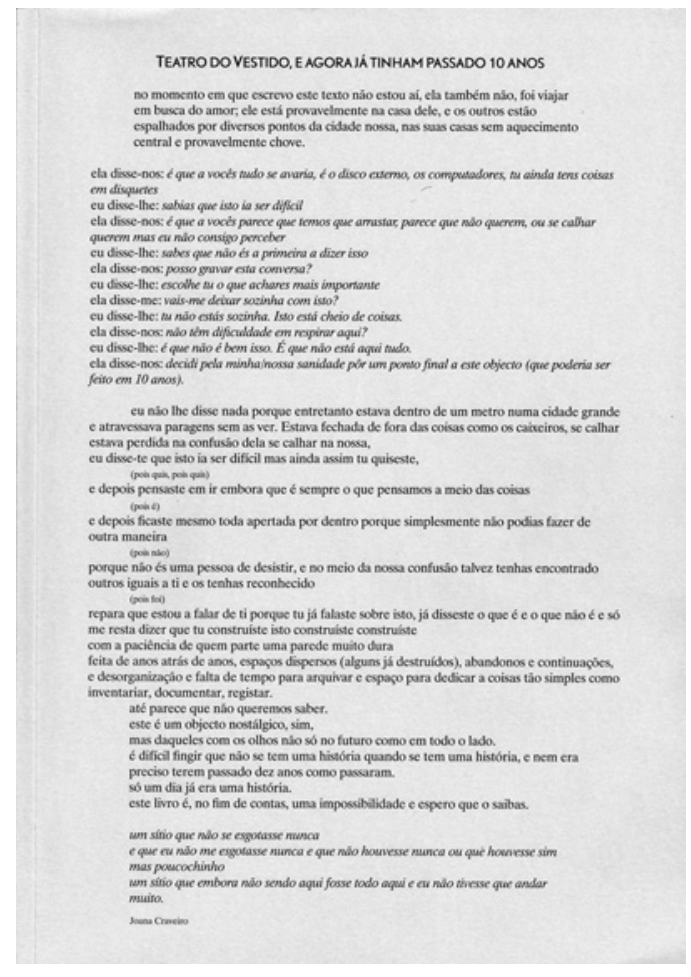

AA.VV., Teatro do Vestido: E agora já tinham passado 10 anos. Concepção Catarina Vasconcelos e Teatro do Vestido. Lisboa: Teatro do Vestido, 2012, 224 pp.

Há qualquer coisa no universo e na prática do Teatro do Vestido que inspira o recolhimento nostálgico e a revisitação poética. Como se, de alguma maneira, se entendesse que o futuro nunca pudesse ser tão solar como o passado. 0 título de um dos seus últimos espectáculos dá precisa conta desta sensação: Agora já tinham passado dez anos e nem sombra deles em lado nenhum (2011). Ainda que a segunda parte deste título possa insinuar alguma acidez, esse não é, certamente, um dos modos preferenciais de acção do Vestido (contudo, refira-se que, a existir, essa acidez seria justíssima, dado que a maior parte dos criadores da sua geração, apanhados num buraco negro entre gerações, parece ter desistido, mudado de vida ou ter passado a última década a recomeçar sempre do zero). Em detrimento da acidez, encontramos amiúde a metáfora poética, a alegoria, a alegria na construção comunitária e no trabalho de pesquisa. Os seus espectáculos (tal como este livro) são frequentemente compostos em torno de fragmentos, pedaços visiveis de histórias de vida e do mundo, umas documentadas, outras inventadas, suportadas por fotografias, cadernos, objectos domésticos, enfim, pela memorabilia esquiva do dia-a-dia.

Teatro do Vestido: Eagora já tinham passado dez anos, celebra os dez anos de existência deste colectivo teatral. É "qualquer coisa contra essa morte a que chamamos esquecimento" afirma Catarina Vasconcelos na "Carta aberta para um Vestido com 10 anos", texto inaugural deste livro. É uma obra singular, ecfrástica, composta por cartas, declarações, fotografias de páginas de cadernos de apontamentos, postais antigos, notas soltas, fotos velhas, esquemas escritos à mão, desenhos, em suma, os mais diversos objectos e materiais que estiveram envolvidos (a montante ou a jusante) na criação dos dezassete espectáculos do Vestido.

0 livro é estruturado em quatro partes: "Cadernos" (pp. 10-55); "Inclassificáveis" (pp. 56-87); "Espectáculos" (pp. 88-207); "Lugares, zonas, postais e um glossário" (pp. 208-207). Em "Cadernos" reproduzem-se, então, em facsimile, cadernos de vários criadores que estiveram envolvidos na criação dos espectáculos (Tânia Guerreiro, Rosinda Costa, Joana Craveiro e Simon Frankel) onde se apontaram ideias, frases soltas, citações, pensamentos, desenhos, esquemas, listas, etc. São traços breves, fugazes, da vida destes artistas durante o processo de gestação de um espectáculo.

Em "Inclassificáveis: Ou coisas que não conseguimos encaixar em sítio nenhum" este livro quase se torna um álbum de fotografias. Publicam-se quinze

fotografias/montagens sobre os mais variados objectos avulsos - daqueles que sobraram de montagens ou que inspiraram encenações - e as suas respectivas legendas (que mais não são do que memórias descritivas da presença dos objectos nas vidas dos criadores e na vida dos espectáculos). Escreve-se - anonimamente ou colectivamente - sobre o "n. 01: telefone(s)", em jeito de programa estético: 
Acho que os objectos se ressentem desse abandono. Acho especificamente que os nossos objectos - de quem nos aproveitámos ao longo de dez anos - se ressentem dessa nossa falta de compromisso para com eles. Como este telefone, por exemplo. Gostava de o reencontrar. (p. 59)

Mas, lá aparecem também cartões, quadros, fotografias, emblemas, vestidos, cartas, posters, bancos de praia, rockets, bilhetes e postais, caixas e luvas. Todos acompanhados pelas explicações que justificam a escolha daqueles objectos em particular e que se prendem, na sua maioria, com as relações subjectivas que estabelecem com os espectáculos que evocam - mas que, ao mesmo tempo, motivam descrições mais objectivas de cenas, ensaios e de episódios concretos.

Em "Espectáculos" continua-se o levantamento desta memorabilia efémera: recortes de jornais, textos de programas, passagens dos textos originais, fac-simile de materiais de trabalho, notas de ensaio, capas de livros, e mais fotografias (de recolhas, de trabalhos com a comunidade, de ensaios e de espectáculos), tudo organizado em torno dos espectáculos e cronologicamente.

Em "Lugares, zonas, postais e um glossário", apresentam-se alguns dos locais importantes no trajecto do Vestido (locais de ensaio, de apresentação, casas, etc.). sendo que "muitos destes lugares são hoje arqueologia" (p. 213). No glossário - assinado por Ana Sofia Paiva, Gonçalo Alegria, Inês Rosado, Joana Craveiro, João Paulo Serafim, Rosinda Costa e Tânia Guerreiro - apresenta-se a gramática própria com que este colectivo trabalha e explicam-se conceitos como "deriva", "colaboração", "pesquisa", entre muitos outros.

0 cuidado primoroso com a apresentação desta obra revela, também ele, uma dimensão performativa: constróise uma narrativa dramatúrgica que empresta, retrospectivamente, sentido a uma década de trabalho. Com efeito, a ideia de dramaturgia, tal como se declara no glossário:

[É] fulcral em tudo o que fazemos. Podiamos dizer que tudo è dramaturgia no nosso trabalho. (p. 219)

Acompanha o livro um "Álbum" e um CD. 0 "Álbum" é constituído exclusivamente por fotografias de espectáculos, de Lugar nenhum (2002) a Agora já tinham passado dez anos...(2011). No CD (sem ficha técnica) oferecem-se quatro faixas de uma paisagem sonora que pode muito bem servir como acompanhamento à leitura do livro.

Esta obra, porque se presta a uma reconstituição dos particulares processos de criação deste colectivo teatral, é uma maneira de entrar na teia criativa do Vestido e uma maneira de contar a história do teatro em Portugal. E é também um objecto de extrema utilidade aos estudos de teatro e, em particular, ao domínio da genética teatral, na medida em que reúne e disponibiliza materiais que estiveram na génese de espectáculos. Contudo, não obstante a singeleza desta obra, não deixo de sentir que se perdeu, de alguma forma, a oportunidade de mobilizar aqui um aparato critico mais substancial. É certo que se publica o texto com que o crítico João Carneiro justificou a atribuição da Menção Especial atribuída pela APCT no âmbito dos Prémios da Crítica 2011 ("Uma das maneiras mais perfeitas de conhecer o presente"); se publica um ensaio de José Alberto Ferreira, investigador e director do Festival Escrita na Paisagem ("O Teatro do Vestido e a paisagem: linhas de um percurso"), um comentário crítico sobre os cinco anos de colaboração e acolhimento do trabalho do Teatro do Vestido no referido festival; e um texto de Maria Gil, encenadora e directora artística do Teatro do Silêncio ("Zona de deriva(s): estratégias de aproximação ao universo do teatro do vestido"); mas a verdade é que os materiais apresentados são quase exclusivamente os produzidos no contexto da criação dos espectáculos. Não é, em si, aspecto despiciendo, mas, a verdade é que o Vestido poderia aqui não ter olhado tão insistentemente para o passado e ter usado este livro como uma plataforma de diálogo entre um passado de riqueza inegável e o seu futuro que embora manchado com a incerteza que paira sobre todas as estruturas culturais em Portugal - se afigura tão criativo como o passado. Mas, por outro lado e pensando melhor: talvez não seja esse um dos modos preferenciais de acção deste colectivo. E se há coisa que esta obra confirma é a robusta identidade estética do Teatro do Vestido. Há dez anos como agora. 